\title{
Functional peculiarities of anaphoric units in the Japanese language system
}

\author{
Irina Victorovna Shalina*, Natalia Yurievna Trazanova, and Anna Valerievna Chaykisova \\ Irkutsk State University, Department of Oriental and Asia-Pacific Studies, 664000, Irkutsk, Russia
}

\begin{abstract}
This article is devoted to the analysis of the anaphoric usage of some Japanese units (copulas, nominalizers, demonstrative pronouns) at the semantic and syntactic levels. The study of anaphoric relations in the language in general and in individual languages in particular is of great interest to linguists conducting research in various areas of modern linguistics. Anaphora has been studied by functional linguists, cognitive linguists, psycholinguists, etc. Anaphoric relations have been described not only in the sentence, but also in the text. Now information about the use of anaphoric means at the level of discourse is considered to be one of the mandatory elements of a comprehensive description of the language or its pronominal system. Pronouns are given special attention, since they function as substitute words and help to make our speech more concise. Anaphoric demonstrative pronouns are used as connecting elements in the text and form intertextual links. They show that there is a predicate that identifies the previous and subsequent fragments of the utterance. Our approach can be characterized as an integral one. We attempt to present a complex description of the usage of anaphoric units in the Japanese language specifying their morphological, syntactic, semantic, pragmatic and communicative properties.
\end{abstract}

\section{Introduction}

Anaphora is treated here as such a relation between linguistic expressions when the meaning paradigm of one expression contains a reference to another one. Anaphoric reference appears when there is no direct syntactical connection, i.e. anaphora is about additional semantic connection with no structural correspondence.

Anaphora is not limited by the frames of a simple or a composite sentence, it often goes beyond. An anaphoric word can determine the semantic link between two sentences that are not connected syntactically. This link connects the following sentence with the preceding one.

Thomas walked in. $\underline{\text { He }}$ was in a hurry.

In this sentence the anaphoric structure is presented by two expressions that are related to the same referent.

\section{Research Methods and Materials}

Most studies in this field have been carried out by psycholinguists and are devoted to some special and technical aspects of the understanding and synthesis of anaphoric pronouns. T. Van Dijk and V. Kintsch pay special attention to the strategies of understanding of this type of pronouns. The authors give several strategies that show how to find the antecedent (i.e. a preceding linguistic expression with which the following expression correlates): recent time period, semantic and syntactic emphasis and topic reference. The last factor is the major one. According to Dijk and Kintsch, shortterm memory buffer manages the interpretation of discourse as it consists of several propositions acquired as a result of the interpretation of the preceding part of the discourse. The antecedent identification takes places in this buffer. Usually it turns out to be the topic [1].

Discourse anaphora has been considered in a number of other theoretical works. The author of one of the most widely known conceptions of discourse organization is M. Halliday [2]. According to him, anaphora as a type of reference among four forms of discourse coherence is the only means of coherence of neighboring predications, thus it has a critical importance for the text formation.

\section{Problem Statement}

Anaphoric coding presupposes the usage of such elements in the text, the dictionary definitions of which comprise semantic relations which can be expressed with the help of units of any lexico-grammatical classes.

This article is devoted to the analysis of functional peculiarities of anaphoric elements in the Japanese language.

\section{Research Questions and Findings}

\subsection{Anaphoric functions of copulas}

Corresponding author: $\underline{\text { i_v_s2000@mail.ru }}$ 
The class of formal words of the Japanese language presupposes the existence of copulas.

Copulas are formal words used as a part of the nominal compound predicate and expressing the verbal categories of tense, mood and voice.

Japanese copulas can be divided into pure (だ da、 です desu、である dearu、でございます degozaimasu) and modal (らしい rashī, にすぎない nisuginai、にかぎらない nikagiranai).

In the Japanese language copulas are used as an important component of such lexico-grammatical types of sentences as characterizing, identifying and existential.

A copula can be used in three different meanings:

1. The presence of some object or situation.

2. The participation of some object in the definite situation or the presence of the definite feature.

3. The identity of two objects.

Let us identify which of these meanings can be considered to be anaphoric.

\subsubsection{The copula status in characterizing sentences}

The usage of a copula in a characterizing sentence has the following peculiarity: syntactically the copula subordinates two noun phrases. The first noun phrase denotes the participant of the situation or the bearer of the feature, and the second noun phrase denotes the situation or the feature correspondingly. Semantically, one of the noun phrases realizes the valency of the other one.

祖母は難聴であった。Grandmother was deaf (lit. Grandmother was deafness).

In this example the noun phrase (祖母 sobo "grandmother") fills the semantic valency of the second noun phrase (難聴 nanchō: “deafness"), i.e. grandmother is represented as the bearer of the feature "deafness".

科学者は新薬の研究の担当である。The scientist is responsible for the research of a new drug (lit. The scientist is responsibility of researching a new drug).

The first noun phrase (科学者 kagakusha “scientist") fills the semantic valency of the second one (担当 tantoo: "responsibility"), i.e. the scientist is represented as the subject of the state "responsibility".

The principle is that such a dictionary interpretation of a lexeme is considered preferable that makes it possible to predict possible syntactic relationships between the lexemes.

The class of lexemes for which this kind of information constitutes an important component of dictionary information is called lexical function parameters (LF parameters). The concept of the LF parameter was described in the works devoted to the study of natural language models [3].

Podlesskaya V. I. analyzes the copula in characterizing sentences as LF parameter. In the example below the noun phrase with predicative status, i.e. a copula component, is considered to be a basic word:

書かない人は負けです。A person who does not write is a loser. (lit. A person who does not write is defeat). This correlation between semantic and syntactic structures corresponds to the definition of the LF parameter [4].

\subsubsection{The usage of copulas in existential sentences}

Another area of the use of the copula is existential sentences. In these sentences the copula functions as a predicate with the meaning "to take place". The valence of this predicate is replaced by the copular component.

角を曲がると新しい図書館の建物であった。

Turning the corner, we saw a new library building (lit. Turning the corner, a new library building took place).

試合に勝つ努力をしなければならないと考える 私です。I think it's necessary to make every effort to win the game (lit. There is me who thinks that it's necessary to make every effort to win the game).

Spatial and temporal localizers (the components of existential sentences) can be syntactically subordinated to the existential copula.

一昨年は大雨だった。It rained heavily last year (lit. Heavy rains took place last year).

あの小豆の味だよ。Oh, what a taste of red beans! (lit. The taste of red beans takes place).

The existential copula realizes a weak semantic valency: the directions of semantic and syntactic dependencies turn out to be opposite here. In terms of lexical functions, such a status of an existential copula in the structure of a sentence can be characterized as an LF parameter, i.e. can be used in anaphoric function.

\subsubsection{Copulas in identifying sentences}

In identifying sentences both the copular component and the noun phrase are used referentially and are related to each other in the process of communication.

これがあのひとか! Here he is! (Lit. This is the very same person).

自然科学に大きく貢献してきたのがこの大学で ある。It is the university that contributed greatly to the natural sciences. (Lit. The one that contributed greatly to natural sciences is this university).

The interpretation of the copula in such sentences includes the meaning of sameness.

The operation of identification as an element of reality is reflected in the natural language being embodied in various linguistic forms. Various language means that represent the operation of identification have a common element in the semantic representation, i.e. the semantic predicate.

The relation of identity can connect semantic units of different degrees of complexity and of different referential attribution; however, the essence of the relation does not change in this case. 


\subsection{Anaphoric functions of nominalizers}

The usage of nominalizers in Japanese is one of the basic means of expressing the relationships of sameness. Here we can talk about anaphoric units with appositive meaning. Two noun phrases are placed in such a way that one element identifies the other one. The noun phrase that contains the nominalizer is called an appositive and its identification must be discussed in detail.

The appositive meaning is typical of the nouns that are generic nominations of a state, an action or a process. Such units can be found in many languages, but their share in the lexicon of different languages may vary. In languages like Russian units of this kind belong to the lexical-syntactic periphery. This is not the case in Japanese.

\subsubsection{The nominalizer こと koto}

The meaning of the nominalizer こと koto can be rendered like this: a fact, an incident, a circumstance, a question, an event, an occupation, a thing, etc.

According to its formal properties, the syntactic group preceding a word with an appositive meaning should be considered to be its attribute, and the presence of this adjective phrase is mandatory. However, the semantic relations between the adjective phrase and the nominalizer can be different.

The interpretation of the nominalizer $こ と$ which can be represented as "some fact, namely, the adjective phrase it refers to", i.e., something real, factual, expressed by the preceding noun phrase.

彼女がその依頼の実行を断る意思があることは その言葉からわかるようになりました。It became clear from her words that she wasn't going to comply with a request. (lit. The fact that she had an intention to refuse to comply with this request became clear from her words). 報告者は仕事はこの先まだたくさんあるこ とを強調した。The reporter emphasized that there was still a lot of work to be done. (Lit. The speaker emphasized the fact that there was still a lot of work to be done).

\subsubsection{The nominalizer わけ wake}

The nominalizer わ け wake (sense, reason, circumstance) also has an appositive meaning.

The interpretation of this nominalizer can be presented as "the situation found at the moment in question, namely the noun phrase".

彼女は猫を一匹と犬を 2 匹飼っている。一人暮 らしで寂しいわけだ。She keeps one cat and two dogs because living alone is sad. (Lit. She keeps one cat and two dogs. The reason is sad loneliness).

このレストランはいつも客がいっぱいだが、だ からといって特別においしいわけではない。 Despite the fact that there are always a lot of customers in this restaurant, it does not have delicious food. (Lit.
This restaurant is always full of visitors, but despite that it's not about delicious food).

実際にはもう彼を採用することに決まっていた が、形式上は面倒でも試験を面接をしないわけに はいかなかった。Despite the fact that the decision to accept him had already been made, formally he had to take the exam. (Lit. In fact, the decision to accept him had already been made, but it did not mean that he did not have to take the exam, even just formally).

\subsubsection{The nominalizers ところ tokoro and ばあい baai}

Let us consider a special class of units made by bivalent nominalizers with an appositive meaning. The most frequently used of them are the nominalizers ところ tokoro and ばあい baai. Constructions with ところ tokoro (place, space, circumstance) are of adverbial nature, because they denote spatio-temporal or logical connection between the situations described.

The interpretation of this nominalizer can be presented as «a situation, a noun phrase, a nominalizer group is related to». It is necessary to distinguish the nominalizer ところ tokoro from the homonymous lexeme with locative meaning.

現在のところ応募者は約 100 人ほどです。 Currently there are about 100 applicants (lit. Now the circumstances are such that there are about 100 applicants).

先生にお願いしたところ、早速承諾のお返事を いただいた。When I asked the teacher, I immediately received a reply of consent. (Lit. The moment I turned to the teacher with a request, I immediately received a positive response).

The nominalizer ばあい baai (case, circumstance, situation) also connects one situation with another one, which is considered to be identical.

火事、地震など、非常の場合には、エレベータ 一を使用せずに階段をご利用ください。In case of emergency such as fire or earthquake, please use the stairs without using the elevator. (Lit. In emergency situations of fire, earthquake, etc. use the stairs without using the elevator).

今は泣いている場合じやないよ。It's not time to cry now. (Lit. It is not the case for crying).

あの場合にはやむをえなかった。 It was unavoidable in that case.

In some cases the object phrase that realizes the semantic valency of the nominalizer can denote not the identical situation, but the participant of this situation.

あなたのばあい、実際に拝見してみなければわ かりません。In your case, you won't know until you actually see it (lit. In this case it's impossible to understand you without inspection).

\subsubsection{The nominalizer の no}

It is necessary to analyze the most abstract nominalizer の no. The syntactical properties of this unit do not allow 
us to classify it as a noun and consider its relations with the predicate as defining. However, the semantic relationship between the nominalizer $の$ no and the syntactic group it refers to is similar to the relationship that other nominalizers enter into.

On the one hand, this nominalizer has an appositive meaning. It is a generalized nomination of a particular event which is in relation of sameness with the event, denoted by the verb phrase it refers to.

小さな虫が道端を張っているのが見えます。

You can see a small insect crawling along the path (lit. A small insect is crawling along the path - it can be seen).

The verb phrase realizes the semantic valency of the nominalizer.

On the other hand, the nominalizer can denote a thing, including animate beings, i.e. a participant of the situation or the thing that carries the feature.

本を読んでいるのは私の友達です。The person reading the book is my friend (lit. The person, who is reading the book, is my friend).

新しい鉛筆が必要です。昨日買ったのをなくし てしまいました。I need a new pencil. I lost the one I bought yesterday (lit. I need a new pencil. The one I bought yesterday was lost).

The analysis shows that the nominalizer realizes the valency of the verb phrase and thus, doesn't have an appositive meaning.

\subsubsection{The nominalizer もの mono}

This nominalizer is a generic nomination of an object which realizes the semantic valency of the object phrase. Nominalizer もの mono can denote an animate or an inanimate object or a state.

私は一度も愛情などというものを感じたことが ない。I have never experienced love. (lit. I've never felt a state like love).

お金を借りたものは鈴木です。Suzuki borrowed money (lit. The one who borrowed money is Suzuki).

We can say that the nominalizer もの mono cannot be referred to the class of units with an appositive meaning.

Thus, the nominalizer $の$ no (in one of its meanings) and the nominalizer $も の$ mono cannot be classified as anaphoric units.

Given all that, we can find appositive meanings in a number of Japanese high frequency words that are classified as nominalizers. Some low frequency words that serve as generic nominations of facts or states can also render appositive meanings, but they are not classified as nominalizers: 事実 jijitsu (fact, reality), 有 様 arisama (condition, state), 状態 jōtai (condition, situation, state), etc.

\subsection{The anaphoric function of demonstrative pronouns}

In most languages the units with the semantic predicate of sameness can function both deictically and anaphorically. Such units are able to activate two mechanisms of informational background common to the participants of the speech act: the reference to the pragmatic characteristics of the speech act (deixis) and the accentuation of two or more fragments of the text, having the same referent (anaphora).

Thus, in some cases we can talk about the combination of anaphoric and deictic components.

Paradigmatic combination takes place when the same unit can be used in one context as a deictic unit, and in another context - as anaphoric.

Syntagmatic combination can be observed when a unit can perform both functions simultaneously in one particular context.

\subsubsection{Structural peculiarities of demonstrative pronouns}

The groups of Japanese demonstrative and interrogative pronouns constitute a coherent system in terms of the derivation method.

The first component of the pronoun shows that it belongs to the so-called series represented by one of the three morphemes: こ- ko-, そ- so-, あ- a-, which depends on the character of relation to one of the participants of the speech act. The first component can be also represented by the interrogative morpheme どdo-.

Morphemes that take the second position in the pronoun show the so-called row of the pronoun, they determine its syntactic class and semantic properties of its referent. The meaning of these parts of speech combines the indication of the relation of the speech segment to the reality with such components as "place", "thing", "property", etc.

It must be noted that the semantic difference is also expressed morphologically: the first morpheme of the pronoun carries the indicative component, while the second morpheme carries other meanings.

The second component of the pronoun is represented by the morphemes: - れ-re, -ちら -tira, -の -no, -こ ko, 一んな -nna.

Modern Japanese has preserved some forms of the "bungo" language, the literary form of the classical Japanese language. The class of pronouns is not an exception. Namely, there is a row of forms with the morpheme なた -nata. For example, the pronoun あな $た$ anata, etymologically dating back to this row, is used as a personal pronoun of the second person singular.

The row こいつ koitsu- そいつ soitsu- あいつ aitsu is used to denote people and things in spoken language.

Since the second morpheme determines the combinability of the pronoun with grammemes, we can identify the acceptable position of the pronoun.

The pronouns これ kore- そ $れ$ sore- あ れ are- or ここ koko- こ soko- あそこ asoko can replace nouns of any semantic class, except for the names of human beings, in any syntactic position, except for the position of the attribute to the noun. In the latter case, the 
pronouns of the series この kono, その sono, あの ano are usually used. They are called relative or attributive because the only acceptable position for them is the position of the attribute to the noun.

There are also pronouns こんな konna, そんな sonna, あ んな anna, which can be combined with grammemes $の$ no and $に$ ni, as well as with the finite form of the copula.

\subsubsection{The anaphoric usage of demonstrative pronouns}

Japanese demonstrative pronouns both in anaphoric and deictic usage have an indicative component of meaning (expressed by a morphemic marker of a series) as well as a nonindicative component, denoting some semantic features of the referent (expressed by a morphemic marker of a row).

The indicative component of the deictic pronoun signals the inclusion of a referent into the speech act. The indicative component of the anaphoric pronoun marks the referent already included into the speech act.

The most detailed analysis of the character of semantic oppositions between the series in anaphoric usage was carried out by Japanese linguist Kuno Susumu [5].

The opposition is whether the interlocutors have any common information about the referent of the anaphoric expression.

If the speaker and the addressee have some common information about the referent, the pronoun of the あ- aseries is used, if they do not have it - the pronoun of the そ-so-series is used.

A：おととい田中さんと会いました。あの人は本 当にいい人ですね。I saw Tanaka the day before yesterday. He is a good man after all.

B: ええ、あの人は親切な人ですよ。Yes, he is very kind.

Both speakers are familiar with Tanaka, so they use the pronoun あの ano.

A: そんなの美人だよ! その人に会ったことがあ

る? What a beautiful woman! Haven't you seen her before?

B：その人、赤いドレスを着ている女の人？ Whom? That woman in a red dress?

Both speakers are not familiar with the woman in red; that is why the pronoun その sono is used.

When dealing with the anaphoric usage of demonstrative pronouns we observe the following: if the speaker uses こ-pronoun indicating a particular referent, the addressee must use the pronouns of other series (あor そ-) talking about the same referent. Also we can find some specific cases of the anaphoric usage of こ pronouns, which appear when the speaker talks about the thing he's interested in. It means that anaphoric pronoun preserves its deictic function.

Another type of the combination of anaphoric and deictic components in the meaning of the pronoun can be observed in such cases when the deictic pronoun refers to a linguistic expression. Japanese demonstrative pronouns perform this function quite often.

これで終わらせていただきたいと思います。Let me finish with this.

このあたりでまとめるべきです。And now it is necessary to sum up.

\subsubsection{Functional peculiarities of anaphoric demonstrative pronouns in Japanese}

The type of anaphora, which may include the indication of both a person or a thing and an event, determines not only the choice of the form of pronoun but also the structure that includes the primary nomination of the referent and its further denotation, characterized by anaphoric relationships.

The nomination of a person or a thing is usually expressed by noun phrases that are syntactic actants in verbal structures. The nomination of an event or a property can be expressed in different ways: by verbal forms as well as by verbal nouns.

Finite verbs are syntactically independent whereas verbal nouns are syntactically dependent.

Subjective forms can substitute not only nouns but also verbal nouns.

Eventive forms of pronouns refer to verbs and verbal phrases that denote events. Even if the antecedent of the eventive form is a noun, it works not as a separate actant, but as a verb phrase. However, eventive forms, as other pronouns, syntactically function as nouns. Verbal structure can take the position of a pronoun only if it has the form of incomplete nomination.

彼は車輪で眠りに落ちた。しかし、そ れは彼が三晚寝ていなかったからでした。

He fell asleep while driving. But it happened because he hadn't slept for three days.

The eventive form それ sore «it/that» refers to the predicate structure $\ll$ He fell asleep while driving».

In order to identify the antecedent correctly we need to know not only the context, but also different ties in reality. Sometimes we have to deal with a complicated utterance where the semantic ties are very weak.

Pronoun repetition can refer to any part of the text we just need a sematic connection. This connection is performed by different elements of the context.

The ability to substitute a verbal structure or a series of such structures serves as a basis for the usage of an eventive form as denoting different situations or their fragments. Even if such a form substitutes a person or a thing, they are identified not as such, but as a part of a particular situation. Denoting facts, an eventive form can indicate any of their aspects, which becomes clear from the context.

\section{Conclusion}

Anaphoric coding is one of the means of expressing the semantic relationship of sameness with the help of lexical units of different lexico-grammatical classes. 
The relationship of sameness can be coded with the help of verbs, e.g. the copula "be". Other groups of lexical units are nominalizers and demonstrative pronouns, performing anaphoric functions.

We described the anaphoric usage of copulas in three sentence types (characterizing, existential and identifying). The interpretation of a copula in identifying sentences includes the semantic predicate of sameness as an absolute component of this relationship. The interpretation of a copula in existential and characterizing sentences includes the predicate as a member of sameness relationship.

Nominalizers and words denoting generalized facts and states are treated as units with an appositive meaning.

Describing the functional peculiarities of demonstrative pronouns, we pay special attention to the combined anaphoric and deictic usage of pronouns. This happens only in certain contexts. In a purely deictic function, pronouns relate directly to the referent, while in the anaphoric function they relate to language units denoting the same referent.
Anaphoric demonstrative pronouns are closely connected with the context; that is why their usage in a particular construction is determined by the semantic properties of this context.

\section{References}

1. A. van Dijk, W. Kintsch Strategies of Discourse Comprehension Teun (New York, Academic Press, 1983)

2. M.A.K. Halliday Linguistic Studies of Text and Discourse (London-New York, Continuum, 2006)

3. Yu.D. Apresyan To the new version of lexical function theory (SPb, 2011)

4. V. I. Podlesskaya The problems of lexical and syntactic semantics. Anaphora in modern Japanese (Moscow, 1990)

5. Kuno Susumu Functional Syntax: Anaphora, Discourse, and Empathy (Chicago, University of Chicago

Press,

1987) 